\title{
Aikuiskoulutuksen arvot ja tavoitteet rakennemuutoksen keskellä
}

Kansanvalistusseura järjesti 17._-18.3.1988 Helsingissä seminaarin, jonka teemana oli Aikuiskoulutuksen arvot ja tavoitteet rakennemuutoksen keskellä. Seminaarin annista julkaistaan tässä numerossa suunnittelupäällikkö Liekki Lehtisalon ja apul. prof. Jukka Tuomiston artikkelit. Seuraavassa poimintoja osasta alustuksia.

Seminaarin ensimmäisen päivän teemana oli aikuiskoulutus rakennemuutoksen välineenä ja tämä lähtökohta hallitsi suurelta osin myös toista päivää. Kansliaministeri Ilkka Kanerva aloitti seminaarin puheenvuorollaan, jossa hän korosti aikuiskoulutuksen merkitystä sekä yhteiskunnan että yksilön kannalta. Pelkästään koulutusta lisäämällä ei ongelmia kuitenkaan ratkaista, koska tarjonta ei aina tavoita niitä, jotka eniten tarvitsisivat koulutusta. Kansliaministeri tähdensi myös yhteistyön ja työnjaon merkitystä; ei ole tarkoituksenmukaista järjestää kaikenlaista koulutusta kaikissa oppilaitoksissa.

Painokkaimmin koulutuksen merkitys hyvinvoinnin turvaajana tuli esiin työmarkkinaosapuolten esityksissä. Selvin ero työnantajien ja työntekijäin näkemyksissä oli siinä, miten aikuiskoulutus rahoitetaan sekä kuinka paljon koulutukseen käytetään työ- ja kuinka paljon vapaa-aikaa.

Apulaisjohtaja Kari Purhonen (STK) esitti aikuiskoulutuksen tavoitteiksi teollisuuden kilpailukyvyn ja tuottavuuden parantamisen, mikä välillisesti merkitsisi myös tuottavuuden parantamista. Koulutus auttaa sekä yritysten että ihmisten joustavaa sopeutumista muutoksiin. Koulutuksen tehtävänä on pitää myös yllä ammattitaitoa ja tukea yksilön itsensä kehittämistä sekä edistää uralla etenemistä.

Koulutussihteeri Jari-Pekka Jyrkänne (SAK) korosti tulevaisuuden rakentamista ihmisten toimesta poliittisin ratkaisuin; rakennemuutoskeskustelun fatalismista olisi siis päästävä. Koulutus ei saa olla keino sopeutua muutoksiin, vaan sen pitää olla keino tehdä muutoksia. Yhteiskunnan tasapainoiselle kehitykselle on tärkeää, että työntekijöille turvataan mahdollisuus koulutuksen avulla pysyä työelämän muutosten tasalla. Tulevaisuuden koulutuksessa oppimisvalmiudet ovat tärkeitä ja raja yleissivistävän ja ammatillisen koulutuksen välillä hämärtyy. Työelämän koulutustarpeet voidaan jakaa kolmeen luokkaan. Tarvitaan henkilöstökoulutusta, jonka suunnitteluun koulutettavilla on mahdollisuus osallistua. Irtisanomis- ja lomautustilanteissa työntekijät voivat siirtyä muihin tehtäviin joko samassa tai toisessa yrityksessä. Yksilöiden omaehtoista koulutusta on tuettava tajoamalla opiskeluaikana riittävä toimeentulo. SAK on esittänyt sovittavaksi koulutusrahastojärjestelmästä, jonka tuotto käytettäisiin pääosassa henkilöstökoulutukseen.

Toisena seminaaripäivänä pohdittiin mm. aikuiskoulutuksen tulevaisuudenkuvaa, sen arvolähtökohtia ja tavoitteita.
Rehtori Juha Sihvonen totesi, että vaikka vapaan sivistystyön tehtäväkäsityksessä on tapahtunut painopisteen muutos sivistyksestä kohti hyötyä ja virkistystä, niin silti perinteiset arvot ovat tähän asti säilyttäneet asemansa. Nyt niiden asema on kuitenkin joutunut koetukselle. Yhteiskuntapolitiikan tehtävä ongelmien korjaajana on kadottamassa merkityksensä. Tilalle on tullut pyrkimys tehokkuuteen, joka esim. koulutuspolitiikassa on merkinnyt tulosvastuullisuuden ja maksupalveluperiaatteen käyttöönottoa. Vapaalla sivistystyöllä on Juha Sihvosen mukaan kaksi vaihtoehtoa: joko taipua postmoderniin kehitykseen tai pyrkiä ajanmukaistamaan perinteiset arvot ja tavoitteet. Edellinen vaihtoehto merkitsee koulutuksen tarjoamista kysynnän mukaan niille, joilla on varaa maksaa riittävän korkea hinta. Jos tavoitteeksi asetetaan perinteisten arvojen ajanmukaistaminen, niin silloin joudutaan ottamaan kantaa ainakin seuraaviin kysymyksiin:

- miten vapaan sivistystyön pitäisi suhtautua aikakauden keskeisiin ongelmiin (esim. ympäristökysymykset)?

— vieläkö vapaassa sivistystyössä pyritään koulutuksellisen tasa-arvon lisäämiseen?

- pitäisikö ja jos pitäisi, niin millä kriteereillä vapaan sivistystyön avata ovet ammatilliselle koulutukselle?

- tuleeko vapaassa sivistystyössä edelleen puolustaa oppilaitosten itsemääräämisoikeutta päättää toimintansa tavoitteista ja sisällöstä?

Pedagoginen sihteerri Ulla Puro TSL:stä piti sivistystyötä elämänhallintatieteenä. Elinikäinen, jatkuva koulutus on muuttumassa iskulauseesta välttämättömyydeksi. Ajatteluun liittyvät taidot tulevat korostumaan: kriittisen suhtautumisen, tietojen hankinnan, käsitteiden ymmärtävän käytön, päättelyn ja perustelemisen taidot tulevat uudelleen arvioitaviksi.

Useissa puheenvuoroissa - $\mathrm{mm}$. apulaisosastopäällikkö Anette Liljeström (AKH) - korostettiin koulutuksen järjestämistä aikuisten koulutustarpeen pohjalta. Opinhaluisten kannalta on toisarvoista, minkä organisaation avulla hän hankkii uusia tietoja ja taitoja. Pääasia on, että koulutus on järjestetty siten, ettei hänen elämäntilanteensa ole esteenä, että hänellä on realistiset mahdollisuudet osallistua. Hallinnon ei tulisi muodostaa esteitä, vaan luoda mahdollisuuksia. Ammatillisen ja yleissivistävän aikuiskoulutuksen rajaa tulisi madaltaa ja osittain liuottaa pois. Miten tämä on käytännössä mahdollista, on kysymys, jonka herätti pitkäaikaisen kokemuksen omaavana prof. Kosti Huuhka. Toivoa vain sopii, että Kosti Huuhkan seminaarissa "nimittämä" kahden naisen ryhmä saisi levitetyksi keskusvirastoissa ajatukselle myötämieltä - ehkä 1990-luvulla päästäisiin sitten sanoista tekoihinkin. 